\title{
WASTE MANAGEMENT STUDY IN THE LAKE BUHI PERIPHERY, BUHI, CAMARINES SUR, PHILIPPINES
}

\author{
JENNIFER M. EBOÑA \\ Central Bicol State University of Agriculture, Philippines
}

\begin{abstract}
Piggery and solid wastes monitoring was undertaken along ten (10) lakeside areas namely : Sta. Elena, Sta. Clara, San Buena, Tambo, Cabatuan, Ibayugan, Salvacion, Iraya, Ipil and Sta. Cruz of Lake Buhi in Buhi, Camarines Sur, Philippines. Key findings include: (1) a total of 331 pigpens (with an average of two heads per pigsty) proliferate the lakeshore; (2) piggery wastes are intentionally washed directly into the lake through flushing; (3) estimated volume of wastes produced is $2,019 \mathrm{~L} /$ day with corresponding organic loading of $0.05 \mathrm{mg} / \mathrm{L}$ which is far below the tolerable limits of $5 \mathrm{mg} / \mathrm{L}$ for class C water or lakewater; and (4) presence of municipal ordinance No. 03040 provides a framework for regulating piggery and other wastes. The findings suggest that wastes from piggery alone cannot be generalized as culprit for water pollution. This is validated by water quality monitoring quarterly report of the Department of Environment and Natural Resources (DENR) which reflects that water conforms to the standard set in terms of Biological Oxygen Demand (BOD) and other significant parameters. While it is true that nature has a self-purification process, however, if not given due attention, piggery wastes may have significant cumulative impact on the lake. However, to ensure the health of the lake and conserve the environment, the following is suggested: (1) aggressive and continuous implementation of above-mentioned ordinance; (2) initiate charging of environmental user fees system (EUFS) especially for major fish cage operators as contributors to lake eutrophication due to fish feeds overload in the course of rehabilitating the lake based on the organic loading (Polluter Pays Principle); (3) pollution prevention/cleaner production $(\mathrm{P} 2 / \mathrm{CP})$ options by establishing biogas systems and composting methods may be considered; and (4) strengthen integrated watershed management practices among stakeholders.
\end{abstract}

Keywords: waste management, piggery wastes, solid wastes, lake management.

\section{INTRODUCTION}

Solid waste is a waste type that includes predominantly household wastes (domestic wastes) with sometimes the addition of commercial wastes collected by a municipality within a given area. They are either solid or semisolid in form and generally exclude industrial hazardous wastes.

Sadly, lakes are not spared from being a dumping ground for these solid wastes especially domestic wastes arising from animal production, thus, resulting to poor water quality.

To date, few of the Philippine lakes have been classified according to their water quality. Of the fifty-six (56) lakes monitored by Environmental Management Bureau offices, only three (3) have been officially classified: Lake Lanao, Lake Nauja and Lake Taal. All are classified as Class B. The largest lake in the country, Laguna de Bay, has not been officially classified.

Lake Buhi is the lake under study and is found in Buhi, Camarines Sur. It has an area of $18 \mathrm{~km}^{2}$ and has an average depth of $8 \mathrm{~m}$. The lake lies in the valley formed by two ancient volcanoes, Mt. Asog and Mt. Malinao. The lake was created in 1641, when an earthquake caused a side of Mt. Asog to collapse. The resulting landslide created a natural dam that blocked the flow of nearby streams. Another theory suggests that it was created by the eruption of Mt. Asog, which is now dormant [1].

The lake is famous since it is one of the few bodies of water that contain the sinarapan (Mistichthys luzonensis) which is the world's smallest commercially harvested fish. 
To this day, it has been declared Water Quality Management Area (WQMA) by Department of Environment and Natural Resources. As such, interventions should be geared towards the protection and conservation of the lake as a significant body of water.

\section{METHODOLOGY}

\subsection{Description of study site}

The study site included ten (10) barangays in the periphery of the Lake Buhi, namely; Sta. Elena, Sta. Clara, San Buena, Tambo, Cabatuan, Ibayugan, Salvacion, Iraya, Ipil and Sta. Cruz.

\subsection{Data collection}

Primary and secondary data were collected for the study.

Primary data pertains to the perspectives and experiences of residents in the lake periphery, and other primary actors in the field, who are implementers "or receivers" of the laws and policies.

Primary data collection was done through conversational interviews, key informant interviews and focus group discussions. The data gathered focused on the community members' awareness of the various policies.

Secondary data gathering was carried out through document analysis.

\subsection{Method of analysis}

This study mainly involved quantitative and qualitative data analyses. Whenever necessary and depending on availability, supporting data are presented in tabular forms, using frequencies and percentages.

Module of Philippine Agricultural Engineering Standards (PAES 414-1:2002 for Waste Management Structures for Agricultural Liquid and Solid Wastes) was used as yardstick for the volume of wastes generated by pigs and the corresponding organic loading or Biological Organic Demand equivalent.

The volume of wastes generated was calculated using the PAES formula:

Volume $=$ manure production, $1 /$ day $\mathrm{x}$ total number of pigs.

Volume of solid wastes generated based on per capita wastes generation was estimated using the following formula:

Volume of solid wastes generated $=$ per capita waste generation rate $\mathrm{x}$ total population .

\subsection{Profile of respondents and key informants from the study sites}

Majority of the respondents and key informants were barangay officials from the ten (10) lakeside barangays and heads of agencies like the Department of Agriculture, Department of Environment and Natural Resources, Municipal Health Office, Municipal Planning and Sanitation Office. 


\subsection{Scope and delimitations}

This study focused on piggery wastes generation and management. It also attempted to consider other solid wastes but was limited to identifying common solid wastes found in tributaries which ultimately led to the vast open area of the lake.

\section{RESULTS AND DISCUSSION}

Piggery pens dotted the lakeshore of Buhi Lake in Buhi, Camarines Sur as shown in Fig. 1. The figure revealed that most pigpens operators construct their piggery structure along the periphery of the lake for obvious reason that wastes is just being flushed into the lake. Sometimes lakewater itself was used to flush wastes into the lake. Thus, water is accessible for cleaning purposes.

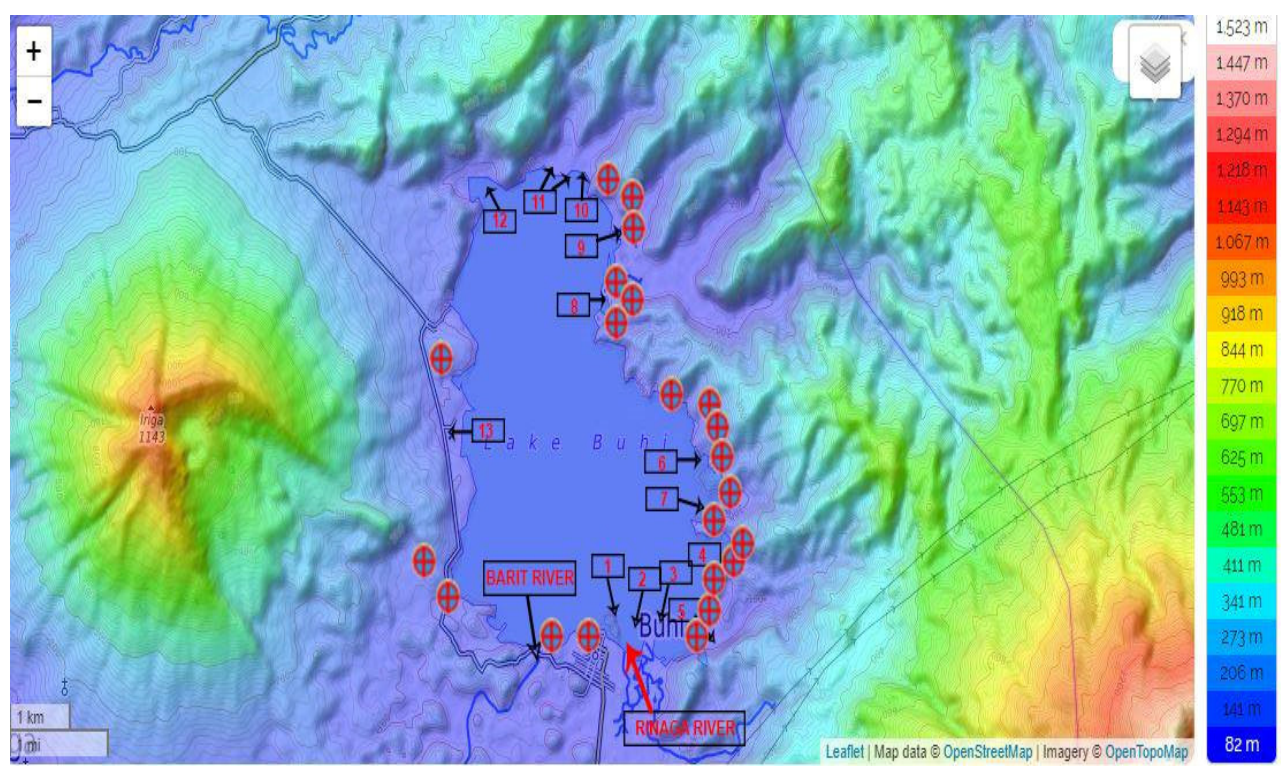

Figure 1: Map of pigpens along the lakeshore of Buhi Lake.

\subsection{Category of production}

Typically, for family-owned operations, each pigpen contains an average of two heads. Thus, it is considered as backyard category. Backyard production is set for less than 20 heads of swine [2]. This is validated by a report by Department of Agriculture that in the hog industry, $77 \%$ of hog inventories remain in backyard production system [3].

Pigpens commonly consist of makeshift open-sided buildings made up of nipa shingles roof and bamboo sidings. Others have corrugated G.I. sheets and CHB wall. All pigpens are placed on concrete slabs.

Commonly made of two cubicles, each pigpen measures $2 \mathrm{~m} \times 3 \mathrm{~m}$ which is partitioned symmetrically with bamboo fence.

Farmers typically clean out these facilities by flushing the floor manually with water. The clean-out water is then discharged directly into the lake as slurry. 
Table 1: Piggery production on lake periphery.

\begin{tabular}{|l|c|c|c|c|c|}
\hline Barangay & $\begin{array}{c}\text { No. of } \\
\text { pigpens }\end{array}$ & $\begin{array}{c}\text { Category of } \\
\text { production }\end{array}$ & $\begin{array}{c}\text { Type of } \\
\text { wastes }\end{array}$ & $\begin{array}{c}\text { Waste } \\
\text { disposal }\end{array}$ & Type of housing \\
\hline Sta. Elena & 15 & Backyard & Slurry & flushing & Makeshift; concrete floor \\
\hline Sta. Clara & 20 & Backyard & Slurry & flushing & Makeshift; concrete floor \\
\hline San Buena & 45 & Backyard & Slurry & flushing & Makeshift; concrete floor \\
\hline Tambo & 40 & Backyard & Slurry & flushing & Makeshift; concrete floor \\
\hline Cabatuan & 30 & Backyard & Slurry & flushing & Makeshift; concrete floor \\
\hline Ibayugan & 47 & Backyard & Slurry & flushing & Makeshift; concrete floor \\
\hline Salvacion & 28 & Backyard & Slurry & flushing & Makeshift; concrete floor \\
\hline Iraya & 40 & Backyard & Slurry & flushing & Makeshift; concrete floor \\
\hline Ipil & 39 & Backyard & Slurry & flushing & Makeshift; concrete floor \\
\hline Sta. Cruz & 27 & Backyard & Slurry & flushing & Makeshift; concrete floor \\
\hline & 331 & & & & \\
\hline
\end{tabular}

Raising pigs is a means of supplementing family's income and a quick way to make extra money. Likewise, pigs are raised in anticipation for fiesta celebration.

\subsection{Type of wastes generated}

Pigs generate waste about $5 \%$ of their body weight. The waste consists of $65 \%$ faeces and $35 \%$ urine. Thus, the combined faeces and urine makes up the slurry. Slurry is high in organic content [4]. Organic wastes are recycled into nutrients that can nourish the tiny forms of life that fed the fish. However, when discharged to water in large quantities, they compete with dissolved oxygen in the process of decomposition. Oxygen is consumed by the decaying matter making the water uninhabitable by fish.

Likewise, pig manure is also high in nitrates and phosphates which may contribute to cultural eutrophication. Eutrophication comes from the Greek word "eutrophos" which means "well nourished". Thus, cultural eutrophication means the over-nourishment of the lake due to cultural practices of man [5].

In an over-nourished lake, too many water plants like water hyacinths and algae grow. These plants later envelope the surface of the water, hampering sunlight to penetrate deeper.

When this layer becomes too thick for light to penetrate, the deeper-lying plants and algae eventually die off and sink to the bottom in a thick brown soup. As a consequence, the lake may die.

\subsection{Volume of wastes generated}

The volume of wastes was estimated based on the Philippine Agricultural Engineering Standards. The estimated volume of wastes produced for all the pigpens along lakeshore is $2,019 \mathrm{~L} /$ day with corresponding organic loading of $0.05 \mathrm{mg} / \mathrm{L} \mathrm{[6]} \mathrm{which} \mathrm{is} \mathrm{still} \mathrm{far} \mathrm{below} \mathrm{the}$ tolerable limits of $5 \mathrm{mg} / \mathrm{L}$ for class $\mathrm{C}$ water [7]. This means that the number of pigpens along the lakeshore is still within the carrying capacity of the lake. 


\subsection{Other wastes in the lake}

It was also observed that petroleum products from navigational boats spillage coat the surface of the lake inhibiting the lake's oxygen intake. Hazards of catching fire may be inevitable, too, posing danger to human life.

Other wastes were also noted in lakeshore and nearby tributaries (Table 2). At the time of the gathering the data, it was noted that majority of the solid wastes were non-biodegradable, meaning they do not decompose in the environment, thus they need proper disposal and not in the lake itself.

Table 2: List of prominent solid wastes on lakeshore and tributaries.

\begin{tabular}{|l|c|}
\hline & Category \\
\hline Worn-out fish nets & Non-biodegradable \\
\hline Pesticide container & Non-biodegradable \\
\hline Old jeans & Non-biodegradable \\
\hline Shells (bugitis) & Non-biodegradable \\
\hline Worn-out rubber slippers & Non-biodegradable \\
\hline Bath/Shampoo sachets & Non-biodegradable \\
\hline Checheria food packs & Non-biodegradable \\
\hline Plastic shopping bags & Non-biodegradable \\
\hline Household items like plates, bowls & Non-biodegradable \\
\hline Baby diapers & Non-biodegradable \\
\hline Sacks (cement, fertilizer) & Non-biodegradable \\
\hline Crude oil & Non-biodegradable \\
\hline Dead fish & Biodegradable \\
\hline Dead water lily & Biodegradable \\
\hline Dead animals & Biodegradable \\
\hline Animal/Human feces & Biodegradable \\
\hline Kitchen wastes (banana peelings, vegetable trimmings) & Biodegradable \\
\hline Dead algae & Biodegradable \\
\hline
\end{tabular}

The municipality of Buhi generates about $0.48 \mathrm{~kg} /$ day per capita [8] as per survey conducted by Save our Future Foundation in 2009. Thus, for the communities within the lake periphery with a total population of 28,255 , it is estimated that about $13,562.4 \mathrm{~kg}$ /day solid wastes is generated.

Table 2 shows solid wastes generated, which are mostly non-biodegradable.

As an offshoot to Republic Act 9003, otherwise known as Ecological Solid Waste Management Act, Municipal Ordinance \#03040 which instills to the people the practice of solid waste segregation to facilitate re-use, recycling and reduce the cost of collection and disposal of garbage. Also littering was prohibited to conserve the natural resources and avoid wasteful consumption of goods. This also limits hog production to only two heads per household with septic tank. However, there are still grey areas in the policy implementation 
which needs to be polished, thus, as of this publication, proliferation of wastes in the vicinity of the lake is still visible.

4 HIGHLIGHTS OF FINDINGS, CONCLUSION AND RECOMMENDATIONS

An investigation of the present state of the environment for Buhi Lake in Buhi, Camarines Sur, Philippines was undertaken. Locale of the study include ten (10) lakeshore barangays namely: Sta. Elena, Sta. Clara, San Buena, Tambo, Cabatuan, Ibayugan, Salvacion, Iraya, Ipil and Sta. Cruz.

\subsection{Findings}

Key findings are: (1) a total of 331 pigpens (with average of two heads per pigsty) proliferate the lakeshore; (2) piggery wastes are intentionally washed directly into the lake through flushing. (3) estimated volume of wastes produced is 2,019 L/day with corresponding organic loading of $0.05 \mathrm{mg} / \mathrm{L}$ which is far below the tolerable limits of $5 \mathrm{mg} / \mathrm{L}$ for class $\mathrm{C}$ [8] water and (4) Municipal ordinance No. 03040 is already in place which served as a policy for regulating piggery and other waste producing sources in the area.

\subsection{Conclusion}

The findings suggest that wastes from piggery alone cannot be generalized as culprit for water pollution. This is validated by Water Quality Monitoring Quarterly Report of DENR which reflects that water conforms to the standard set in terms of biological oxygen demand and other significant parameters. While it is true that nature has a self-purification process, however, if not given due attention, piggery wastes may have significant cumulative impact on the lake.

\subsection{Recommendations}

To ensure the health of the lake and conserve the environment, the following is suggested: (1) Implement aggressive and continuously pursue the implementation of the Municipal Ordinance \# 03040 which instills to the people the practice of solid waste segregation to facilitate re-use, recycling and reduce the cost of collection and disposal of garbage. Also littering was prohibited to conserve the natural resources and avoid wasteful consumption of goods. This also limits hog production to only two heads per household with septic tank (2) Initiate charging of environmental user fees system (EUFS) for piggery owners and fish cage operators in the course of rehabilitating the lake based on the organic loading to the lake (Polluter Pays Principle) (3) Consider Pollution prevention/ cleaner production (P2/CP) options such as establishment of biogas systems and composting methods may be considered for piggery production, and (4) Strengthen integrated watershed management practices among key players in the area.

\section{ACKNOWLEDGEMENT}

Acknowledgement is due to the Philippine's Commission on Higher Education (CHED) Region V under Disbursement Acceleration Program (DAP) for the funds granted to this study.

\section{REFERENCES}

[1] Lake Buhi, https://en.wikipedia.org/wiki/Lake_Buhi. Accessed on: 15 Dec. 2017.

[2] International Training Center for Pig Husbandry Report (ITCPH), pp. 75-76, 2011. 
[3] Department of Agriculture Annual Report, pp. 48-49, 2013.

[4] NRCS, USDA, Agricultural Waste Management Field Handbook. www.nrcs.usda.gov/wps/portal/nrcs/detailfull/national/water/?\&cid=stelprdb1045935.

[5] Eutrophication: Causes, Consequences, and Controls in Aquatic Ecosystems. www.nature.com/scitable/knowledge/library/eutrophication-causes-consequences-andcontrols-in-aquatic-102364466 (C) 2013 Nature Education.

[6] Module of Philippine Agricultural Engineering Standards (PAES 414-1:2002 for Waste Management Structures for Agricultural Liquid and Solid Wastes), pp. 405-410, 2002.

[7] Water Quality Guidelines and Effluent Standards and its Implementation in the Philippines.

http://wepa-db.net/3rd/en/meeting/20160728/PDF/S1_Philippines_DENR.pdf.

[8] Save our Future Foundation Annual Report, pp. 89-91, Philippines, 2009. 